\title{
Experimental Evaluation of DG's Dynamic Voltage Support Capability Improving Short-Term Voltage Stability on Power System Loads
}

\author{
Tomoyuki Ueda Member (Hokuriku Electric Power Company, ueda.tomoyuki@rikuden.co.jp) \\ Shintaro Komami Member (Hokuriku Electric Power Company, komami.shintaroh@rikuden.co.jp)
}

Keywords: power system, short-term voltage stability, voltage sag, distributed generation, low voltage ride-through, dynamic voltage support

Retirement of aged thermal generatiors causes increase of electric distance from total generation to total load. In this situation, high DG (Distributed Generation) penetration may cause serious stability problems on power system. The authors have presented that high DG penetration could lead to short term voltage instability of load in bulk power system and DG's Dynamic Voltage Support (DVS) capability could prevent the instability by simulation methods, which considered load branch impedance and load's dynamic behavior. However, experimental evalutaion of the capability doesn't exist yet.

This paper presents the effect of DVS capability of DG on an experimental set up, which consists of an induction motor, a resietance load, and a compensation capacitor behind a series reactance as shown in Fig. 1. Response of a DG whose active and reactive power output are controlled conrresponding to its terminal voltage is shown in Fig. 2. Character of reactive power is very like to that of SVC, and active power is controlled as a constant impedance to avoid over current in low voltage. By using voltage sag generator, the various tests confirm that the DG sucsessfully realizes low voltage ride through (LVRT) capability and PQ control ensuring DVS capability.

Figure 3 shows the results of voltage sag tests using three types of DGs as follows.

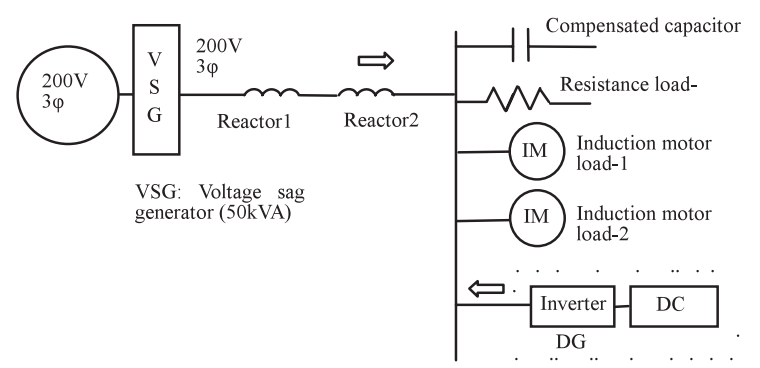

Fig. 1. Schematic diagram of experimental circuit
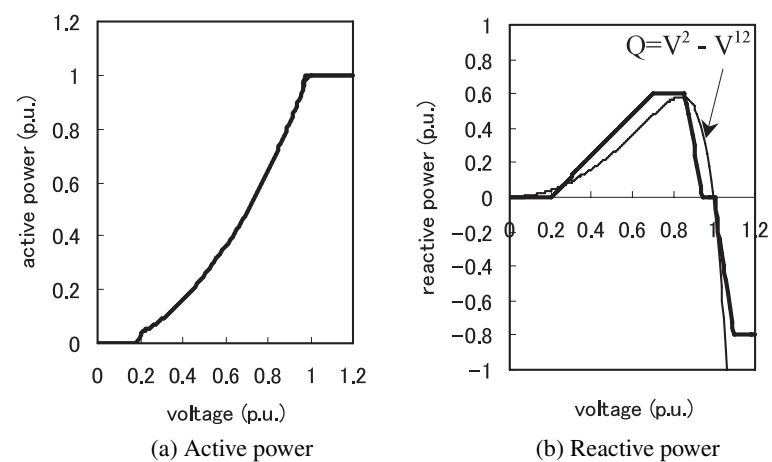

Fig. 2. PQ control method of DG
Type1: drops due to voltage sag

Type2: has only LVRT capability

Type 3: has LVRT + DVS capability

Type 2 is stable in case of fault duration time $\Delta \mathrm{t}=100 \mathrm{~ms}$ and depth of votage sag $\Delta \mathrm{V}=70 \%$ in Fig. 3(a), and it is unstable in case of $\Delta \mathrm{t}$ $=70 \mathrm{~ms}$ and $\Delta \mathrm{V}=100 \%$ in Fig. 3(b). Voltage recovery of type 3 is faster than that of type 2 as shown in Fig. 3(a). According to experimental results, type 3 is even stable in case of $\Delta \mathrm{t}=300 \mathrm{~ms}$ and $\Delta \mathrm{V}=$ $100 \%$, and DVS capability can greatly improve short-term voltage stability of power system load.

Figure 4 shows the results of DG output of type 3 in case of $\Delta t=$ $70 \mathrm{~ms}$ and $\Delta \mathrm{V}=100 \%$. The black line in Fig. 4(a) shows PQ reference conrresponding to measured voltage. Good agreement with black line and PQ output means that DG inverter realizes adequate PQ control as shown in Fig. 2. In Fig. 4(b), DG current is within $150 \%$ of rated current, which is permissible range of short term over current. This paper also points out that the experimental results give good agreement with simulation and analysis using torque-speed curve of induction motor.
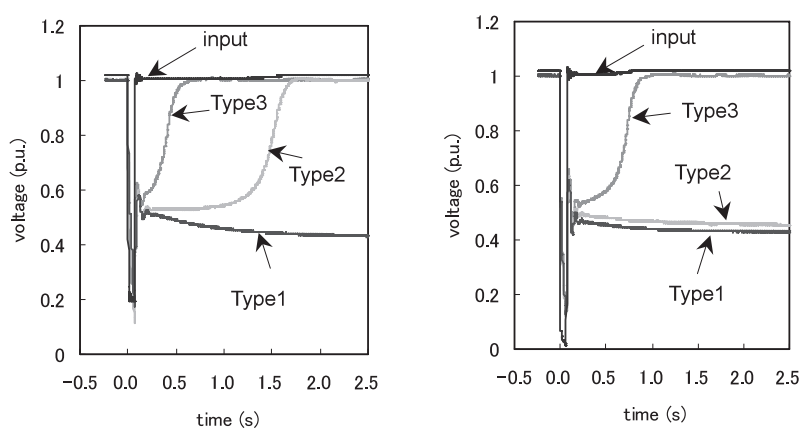

(a) $\Delta \mathrm{t}=70 \mathrm{~ms}, \Delta \mathrm{V}=70 \%$

(b) $\Delta \mathrm{t}=70 \mathrm{~ms}, \Delta \mathrm{V}=100 \%$

Fig. 3. Different load stability due to different DG control
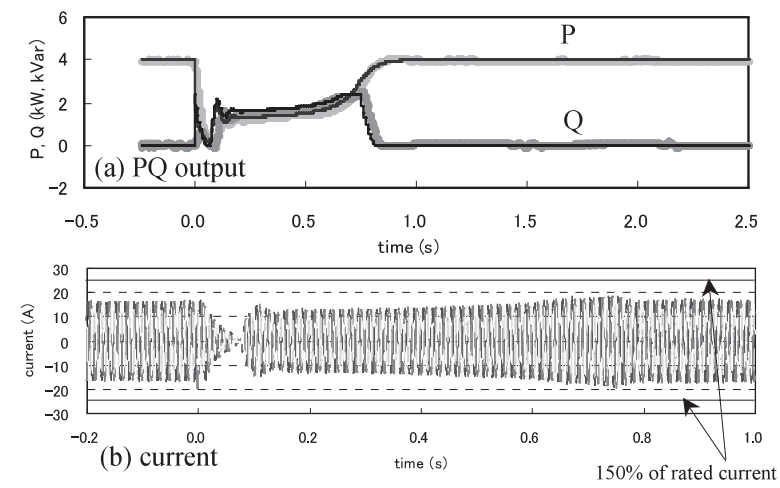

Fig. 4. Output of DG with DSV $(\Delta \mathrm{t}=70 \mathrm{~ms}, \Delta \mathrm{V}=$ $100 \%)$ 


\title{
系統負荷の短時間電圧安定性を改善する分散型電源の 動的電圧維持機能の実験的評価
}

\author{
正 員 上田 智之* 正 員 駒見慎太郎* \\ Experimental Evaluation of DG's Dynamic Voltage Support Capability \\ Improving Short-Term Voltage Stability on Power System Loads \\ Tomoyuki Ueda*, Member, Shintaro Komami*, Member
}

\begin{abstract}
High DG penetration will seriously spoil short-term voltage stability of load in bulk power system. Simulation results on previous studies by the authors have shown that dynamic voltage support (DVS) capability of DG improves the stability, but experimental evaluation doesn't exist yet. This paper presents the effect of DVS capability of DG on an experimental circuit, which consists of an induction motor, a resistance load, and a compensation capacitor behind a reactance. First, an experimental set up that causes voltage instability without DVS is made up. Second, an improvement in DG inverter control is made to realize low voltage ride-through (LVRT) capability and DVS capability, and the DG's performance is confirmed by voltage sag tests. Finally, the tests on the experimental set up demonstrate that DVS capability improves greatly short-term voltage stability of power system loads, and the experimental results give good agreement with simulation results.
\end{abstract}

キーワード : 電力系統, 短時間電圧安定性, 瞬時電圧低下, 分散型電源, 低電圧乗り切り, 動的電圧維持

Keywords: power system, short-term voltage stability, voltage sag, distributed generation, low voltage ride-through, dynamic voltage support

\section{1. まえがき}

近年, 大規模電源の増大, 老朽化火力の廃止により電源と 負荷の電気的距離がますます遠くなる傾向にある。このよ うな状況において, 分散型電源 (DG) の導入が進むと, 負 荷の短時間電圧安定性 ${ }^{(1) ~(3)}$ が低下し, 上位系統への影響も 無視できなくなることが懸念される。著者らはこれまでに, 系統故障などに起因する瞬時電圧低下 (瞬低)により，負荷 の短時間電圧不安定現象 ${ }^{(3)}$ や上位系統の発電機脱調現象 ${ }^{(4)(5)}$ が発生する可能性を示してきた。またその対策として DG が動的に電圧を維持する DVS (Dynamic Voltage Support) 機能を備えていれば，これらの不安定現象が回避できること をシミュレーションにより示した。今後, DVS 機能を備え たDG を実際の系統に導入していくためには，シミュレー ションのみならず，主要因である負荷の短時間電圧不安定 現象を実験で再現し, DG の DVS 機能の効果を検証してお くことが重要となる。

\footnotetext{
*北陸電力 (株) 技術開発研究所

于 930-0848 富山市久方町 2-54

Engineering Research \& Development Center, Hokuriku Electric Power Company

2-54, Hisakatamati, Toyama 930-0848
}

近年においては，自励式素子によるインバータの普及が 進み，インバータ制御の設計次第では DVS 機能を備えた DG の実現は可能であると考えられる。しかし, 現在, 下 位系統に設置されるインバー夕連系の DG は系統安定化効 果を期待されていないため, 系統故障除去直後に効果的に DVS 機能を発揮するDG は開発されていない。インバータ 装置でDVS 機能を実現するためには，11瞬低でも運転継続 する LVRT (Low Voltage Ride-Through) 機能を持つこと, (2DVS 機能の追加に伴い許容過電流を超過しないことが大 切であり，これらに留意した設計や性能試験を行っておく ことが必要となる。

本論文では, DVS 機能付きインバー夕連系装置を製作し, 実験にてその効果を検証した結果を示す。まず，誘導機の トルクー速度曲線とシミュレーションにより, DGを考慮し た負荷の短時間電圧安定性を検討する。これより, DVS 機 能の効果を検証する実験回路の短時間電圧安定性を把握す る。次に, 提案する制御方法を実現するインバー夕連系装 置の概要とその単体試験結果について述べる。特に, LVRT 機能を実現していること, 短時間許容過電流内で DVS 機 能のために適切な有効電力・無効電力制御を実現している ことを示す。そして, DG と誘導機を含む実験回路にて負 荷の短時間電圧不安定現象を再現し, DG の DVS 機能の追 
加によって大幅にその安定性が改善されることを示す。

\section{DG を考慮した負荷の短時間電圧不安定現象}

著者らは，これまでに基幹系統から下位系統を含む大規 模系統について，負荷までのインピーダンスを考慮するY 結線縮約法を適用すると，系統によっては発電機内部一負 荷端子までの電気的距離が非常に遠くなり，負荷の短時間 電圧不安定現象が発生することを示している(3)。また，こ の中で，系統状態や定インピーダンス $(\mathrm{Z})$ 負荷を考慮し誘 導機（IM）負荷のトルク-速度曲線を描くことで，負荷の 短時間電圧安定性を評価する方法も示している。この方法 を利用し，無限大母線〜負荷端子までの電気的距離が非常 に遠い大規模系統において，定 Z 負荷と IM 負荷に DG が 追加された図 1 のような状態を想定する。ここで， $\mathrm{V}_{\mathrm{G}}$ は 無限大母線電圧, $\mathrm{V}_{\mathrm{LT}}$ は負荷端電圧, $\mathrm{X}_{\mathrm{S}}$ は無限大母線から 負荷端子までのリアクタンス， $\mathrm{X}_{\mathrm{LZ}}$ は定 Z 負荷のリアクタ ンス， $\mathrm{X}_{\mathrm{LM}}$ は IM 負荷のリアクタンス， $\mathrm{R}_{\mathrm{LZ}}$ は定 $\mathrm{Z}$ 負荷の 抵抗， $\mathrm{R}_{\mathrm{IM}}$ は IM 負荷の抵抗， $\mathrm{P}_{\mathrm{LM}}$ は IM 負荷の消費有効電 力, $\mathrm{P}_{\mathrm{LZ}}$ は定 $\mathrm{Z}$ 負荷の消費有効電力, $\mathrm{P}_{\mathrm{DG}}$ は $\mathrm{DG}$ の有効電 力出力, $\mathrm{B}_{\mathrm{C}}$ は補償用コンデンサのサセプタンス, $\mathrm{G}_{\mathrm{DG}}$ は DG のコンダクタンス， $\mathrm{B}_{\mathrm{DG}}$ は DG のサセプタンスを表す。 また，DGについては下記に示すような 3 種類が運転した 場合について考える。

Type1：瞬低により停止

Type2 : LVRT 機能のみ

Type 3 : LVRT 機能 + DVS 機能

本論文では DG の有効電力出力は, 系統電圧に対して 2 乗 特性を持つマイナスの負荷とし, Type2 の LVRT 機能のみ の場合は，一定のマイナス抵抗とする。Type3 の DVS 機能 は (1) 式のようなサセプタンス $\mathrm{B}_{\mathrm{DG}}$ で表現する。

$$
B_{D G}=G_{D G}\left(1-\left(V_{L T} / V_{L T 0}\right)^{10}\right)
$$

表 1 の系統状態に扔いて, IM のトルク一速度曲線を求め た結果を図 2 に示す。表 1 において， $\omega_{0}$ は IM の定格回転 数, $\omega$ は回転数, $\mathrm{R}_{\mathrm{IM} 0}, \mathrm{~V}_{\mathrm{LT} 0}$ はそれぞれ $\mathrm{R}_{\mathrm{IM}}, \mathrm{V}_{\mathrm{LT}}$ の定常 状態での值を示す。特に, Type3 の DVS 機能を有する場合 については，ニュートン法に準ずる方法により収束計算を

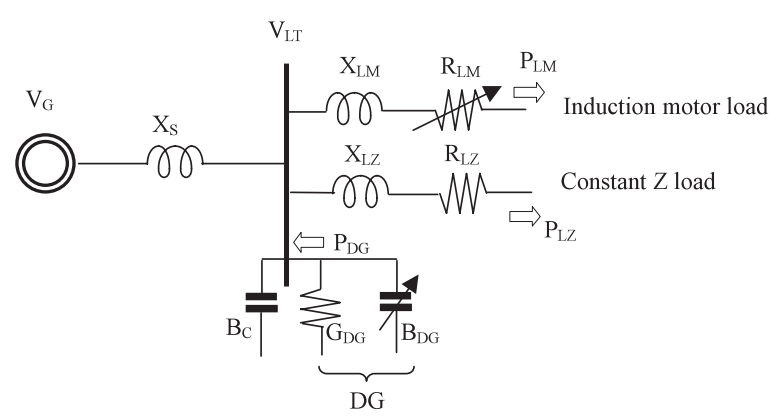

図 1 DG を考慮した短時間電圧安定性解析モデル

Fig. 1. Model for short-term voltage stability analysis considering DG.
行った。図 2 の縦軸は IM の電気的トルク $\mathrm{T}_{\mathrm{e}}$ から機械的卜 ルク $\mathrm{T}_{\mathrm{m}}$ を差し引いた值であるが, 減速時に $\mathrm{T}_{\mathrm{m}}>\mathrm{T}_{\mathrm{e}}$ とな ればIMはストールに至る。Type1 や Type2 のようにDVS 機能がない場合は, IM の回転速度が $80 \%$ 程度で IM は不 安定になり, Type3のようにDVS 機能がある場合は回転速 度が $60 \%$ 程度まで低下してもストールに至らない。図 3 に 表 2 の IM 定数を用いて故障除去時間 $100 \mathrm{~ms}$, 電圧低下率 100\%の故障を与えた場合のシミュレーション結果を示す。

\section{表 1 系統の諸定数}

Table 1. Power system condition (p.u., $10 \mathrm{kVAbase}$ ).

\begin{tabular}{l} 
(a) $\mathrm{V}_{\mathrm{G}}=1.02, \quad \mathrm{~V}_{\mathrm{LT}}=0.99, \quad \mathrm{X}_{\mathrm{S}}=0.30$, \\
$\mathrm{P}_{\mathrm{L}}=\mathrm{P}_{\mathrm{LM}}+\mathrm{P}_{\mathrm{LZ}}=1.5, \quad \mathrm{P}_{\mathrm{LM}} /\left(\mathrm{P}_{\mathrm{LM}}+\mathrm{P}_{\mathrm{LZ}}\right)=0.6, \quad \mathrm{P}_{\mathrm{DG}}=-0.4$ \\
$\mathrm{Bc}=0.3814, \quad \mathrm{R}_{\mathrm{IM} 0}=1.0503, \mathrm{R}_{\mathrm{IZ}}=1.5754$, \\
$\mathrm{X}_{\mathrm{LZ}} / \mathrm{R}_{\mathrm{LZ}}=\mathrm{X}_{\mathrm{LM}} / \mathrm{R}_{\mathrm{IM}}=0.18 / \mathrm{P}_{\mathrm{L}}, \quad \omega_{0}=0.970, \quad \mathrm{~T}_{\mathrm{m}} \propto \omega^{2}$ \\
\hline (b) Type1. $: \mathrm{G}_{\mathrm{DG}}=0.0, \quad \mathrm{~B}_{\mathrm{DG}}=0.0, \quad\left(\mathrm{~V}_{\mathrm{LT}}=0.9186\right)$ \\
Type2. : $\mathrm{G}_{\mathrm{DG}}=-0.4081, \quad \mathrm{~B}_{\mathrm{DG}}=0.0$ \\
Type3. : $\mathrm{G}_{\mathrm{DG}}=-0.4081, \quad \mathrm{~B}_{\mathrm{DG}}=\mathrm{G}_{\mathrm{DG}}\left(1-\left(\mathrm{V}_{\mathrm{LT}} / \mathrm{V}_{\mathrm{LT} 0}\right)^{10}\right)$ \\
\hline
\end{tabular}

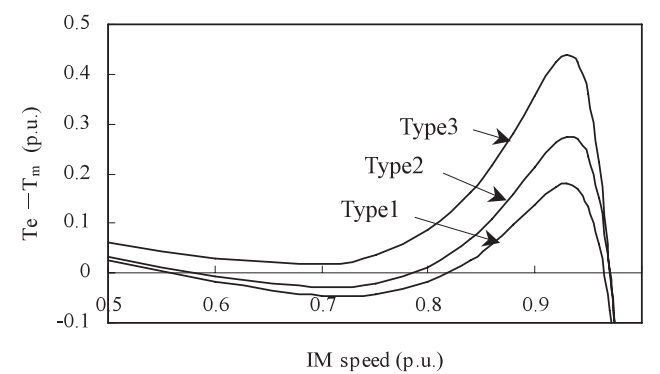

図 2 異なる DG 制御による誘導機トルク一速度曲線

Fig. 2. IM torque-speed curves by different DG control.

表 2 IM の諸定数

Table 2. Parameters of induction motor (p.u., machine base).
Magnetizing reactance $X_{m}=2.3$,

Resistance $\mathrm{R}_{1}=\mathrm{R}_{2}=0.03$,

Leakage reactance $X_{1}=X_{2}=0.1$,

Unit inertia constant $\mathrm{M}=0.5(\mathrm{~s})$,

Loading $=1.0($ rated $\mathrm{kW}$ base $)$

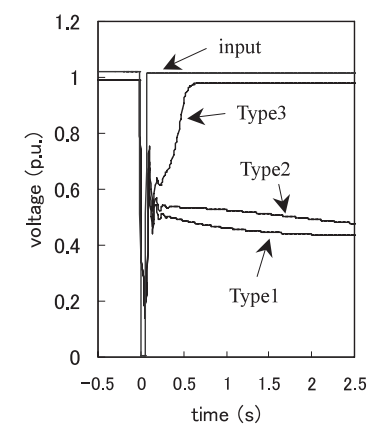

(a) Load's voltage

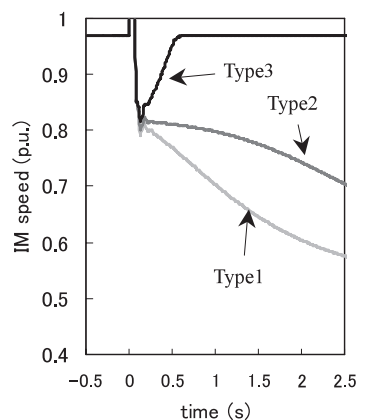

(b) IM speed
図 3 異なる DG 制御による負荷の安定性

Fig. 3. Different load stability by different DG control. 
尚，シミュレーションには電中研 Y 法を使用した。Type1 や Type2 の場合, 負荷端の電圧は回復せず, IM の回転数 は 80\%程度まで低下した後, さらに回転数が低下していく ことがわかる。Type3 の場合は, 電圧, IM の回転数ともに 定常状態まで回復する。

以上, IM のトルクー速度曲線と Y 法シミュレーション結 果から, 表 1 のような負荷 $15 \mathrm{~kW}$, うち誘導機負荷が $60 \%$, DG 出力 $4 \mathrm{~kW}$, 上位系統のリアクタンス 0.30 (p.u.) 程度 であれば，負荷の短時間電圧不安定現象が再現でき，DG の DVS 機能の効果が検証できると考えられる。次章では, 表 1(b)にほぼ近い特性を示すインバー夕連系装置を実際に 製作する。

\section{DVS 機能付きインバータ連系装置}

$\langle\mathbf{3} \cdot \mathbf{1}\rangle$ 作成した装置の概要 本論文で対象とする分 散型電源の種類として, 三相で連系し, 瞬低発生時に発電側 のエネルギー抑制がある程度可能なもの（二次電池，燃料 電池，太陽光発電など）を想定した。瞬低中のエネルギー 抑制が困難な風力発電などは, 別途, エネルギー蓄積用の 装置の検討が必要となる。ここで, 図 4 に示すような制御 を行う市販の連系インバータ装置をべースとした。この装 置は太陽光発電用に製作されたもので昇圧チョッパ，連系 インバータからなり，3相 $200 \mathrm{~V}$ で商用電源に連系し，イ ンバータの定格出力は $4 \mathrm{~kW}$ である。特に，灰色で囲んだ 部分で系統電圧に対する $\mathrm{P}, \mathrm{Q}$ 值を与えるよう制御プログラ ムのみを変更し, DVS 機能の追加を試みた。

表 1(b)の Type3 の出力制御をインバータで行う場合, 有 効電力については, 系統電圧 V の 2 乗に比例した (2) 式の 制御を行うことになる。無効電力については, (1) 式のサセ プタンス $\mathrm{B}_{\mathrm{DG}}$ に系統電圧 $\mathrm{V}\left(=\mathrm{V}_{\mathrm{LT}} / \mathrm{V}_{\mathrm{LT} 0}\right)$ の 2 乗を掛けれ ば，先の論文 ${ }^{(3) \sim(5)}$ で示したような (3) 式の制御になる。こ こで, W は定格出力 $(\mathrm{kW})$ を示す。

$$
\begin{aligned}
& P=W V^{2} \ldots \ldots \ldots \\
& Q=W\left(V^{2}-V^{12}\right)
\end{aligned}
$$

(2)，(3) 式を参考にして，本論文において実際に行った DG 制御方法を図 5 に示す。ここで, 下記のような点につ いて留意し，制御の設計を行った。

（1）汎用インバー夕は $150 \% 1$ 分間程度の過電流耐量 を持つことから, 今回, 短時間許容過電流 (数秒オーダー) の目安を $150 \%$ とし設計を行った。実際に, 過電流耐量が 小さいインバー夕に対しては，その範囲内での制御設計が 必要になる。

（2）常時の運転電圧では定格または最大出力で運転す るものとし, 系統擾乱時の大幅な電圧低下時のみ有効電力 を抑制し，電圧上昇時は有効電力にリミッタを設けた。

（3）瞬低による負荷脱落などの影響で，故障除去後に 系統電圧が過渡的に上昇する可能性がある(3)。そのため, 無 効電力制御により故障除去後の電圧上昇を許容過電流範囲 内で極力抑制するようにした。

（4）定常状態で過敏に無効電力制御を行わないために 不感帯を設けた。

（5）系統電圧がほとんどない状態では位相検出が困難 になり運転継続が難しくなるため, 出力を一旦停止するこ ととした。ここで, 瞬低発生前後で系統周波数はほとんど 変化しないため, 瞬低発生直前の周波数を保持して瞬低中 も位相を計算しておき，電圧復帰直後にはインバー夕を即 時に出力できるように設計した。今回は, 系統電圧 $20 \%$ 以

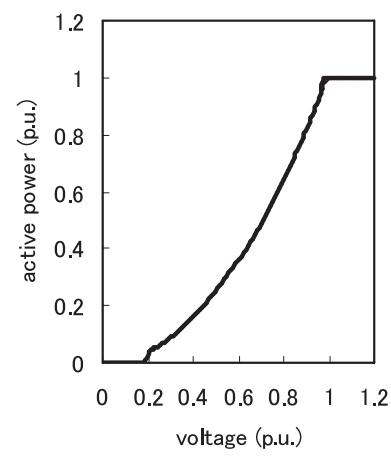

(a) Active power

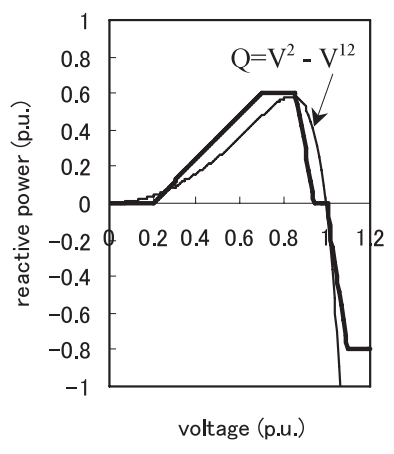

(b) Reactive power
図 5 DG の PQ 制御方法

Fig. 5. PQ control method of DG.

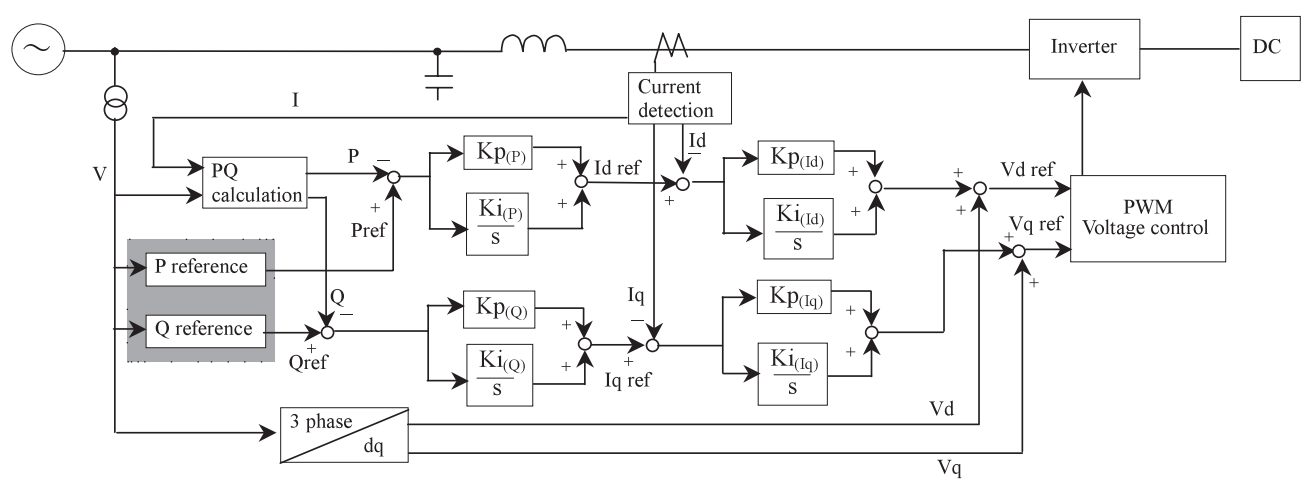

図 4 インバータ制御ブロック図

Fig. 4. Schematic diagram of DG inverter control. 

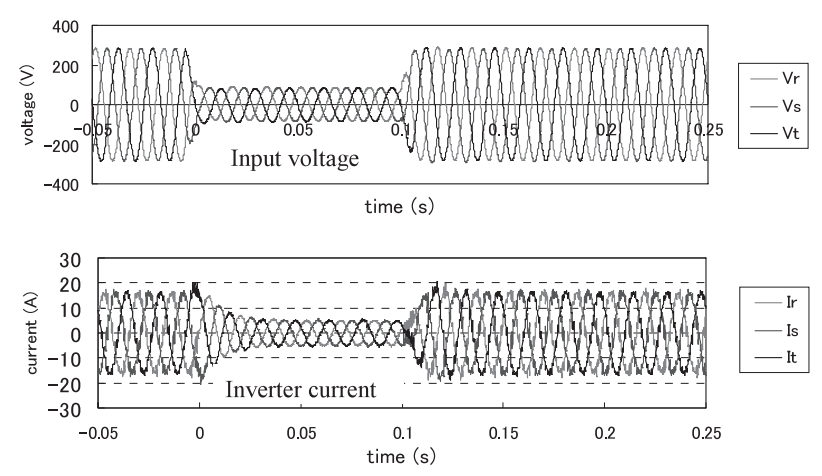

(a) $\Delta \mathrm{V}=70 \%$
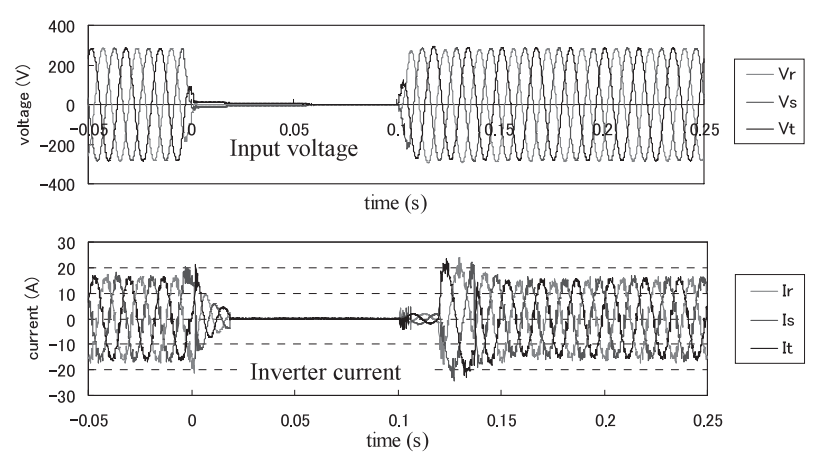

(b) $\Delta \mathrm{V}=100 \%$

図 6 DG 出力の瞬時值波形

Fig. 6. Instantaneous value waveform of DG output.

下で出力を一旦停止し，系統電圧 30\%以上となった場合に 出力を再開するようにした。

市販の連系インバー夕装置について補足すると, 瞬低時 に，直流側の電圧は昇圧チョッパの制御遅れなどにより若 干上昇するが，100 $\mathrm{ms}$ 程度であれば平滑化直流コンデンサ $(3000 \mu \mathrm{F})$ により一定（目標值 $365 \mathrm{~V}$ に対し 104\%以内）に なるように設計されている。また，受動型単独運転防止装 置の電圧位相跳躍検出が装備されていたが, 不平衡故障時や 三相電圧がゼロに近い場合に, 瞬時に位相急変を検出し解列 するようになっていたため，これをロックし実験を行った。

$\langle\mathbf{3 \cdot 2}\rangle$ 瞬低発生装置を用いた運転性能の確認 電力 回生機能付き瞬低発生装置 ${ }^{(6)}$ を用いて, 電力系統で発生す る瞬低現象を再現し，インバー夕連系装置の運転性能を確 認した。図 6(a) に電圧低下率 70\%, 継続時間 $100 \mathrm{~ms}$ の瞬 低試験の結果を示す。この場合は, 瞬低中でも DG の出力 電流は継続しており，運転継続している。図 6(b) に示すよ うに電圧低下率 $100 \%$ ，継続時間 $100 \mathrm{~ms}$ の瞬低試験の結果 では, 出力電流を一旦停止し, 電圧復帰後, 約 1 サイクル程 度で DG は出力を再開している。これは，系統電圧 $20 \%$ 以 下で出力を一旦停止するという設計によるものである。電 圧検出とインバー夕制御の遅れの影響で出力再開が 1 サイ クル程度遅れるが，DGによって故障除去後数百 $\mathrm{ms}$ での 系統安定化効果を期待すればよいことから，LVRT 機能と しては許容できる範囲である。

次に，電圧に対する $\mathrm{DG}$ の $\mathrm{PQ}$ 出力值を確認するために，

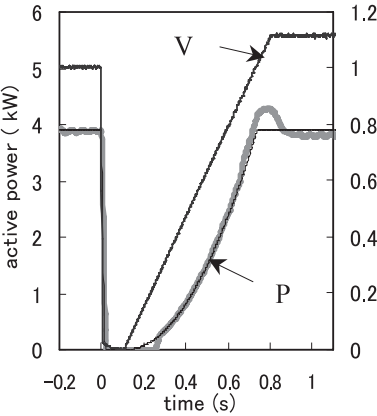

(a) Active power

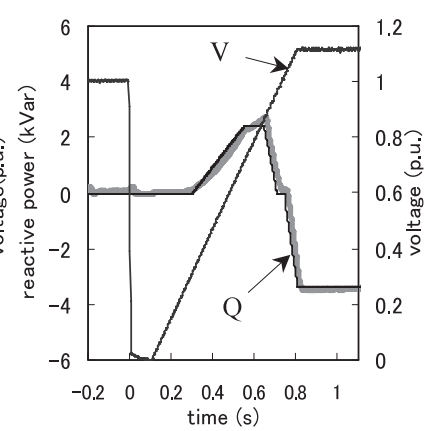

(b) Reactive power
図 7 電圧変化に対する $\mathrm{DG}$ の $\mathrm{PQ}$ 出力

Fig. 7. PQ output of DG due to voltage variation.

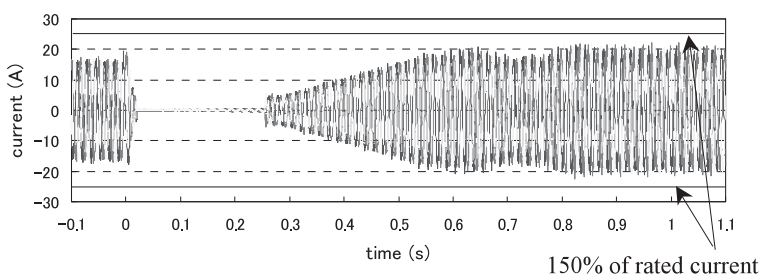

図 8 瞬低によるDG の電流（瞬時值）

Fig. 8. DG current due to voltage sag (instantaneous value).

瞬低復帰時の電圧回復を 0 から 1.11 (p.u.) まで $700 \mathrm{~ms}$ で 線形に変化させた場合の DG 出力を図 7 に示す。若干の制 御遅れはあるものの出力設定值（黒線）とほぼ同等の值が 出力されており，作成したインバー夕装置で設計した特性 （図 5）が実際に得られている。この時の DG の電流（瞬時 值）を図 8 に示す。ここで，設計した有効・無効電力制御 による DG の出力電流は，短時間許容過電流の目安とした 定格電流の $150 \%$ 以内となっている。

\section{4. 模擬系統を用いた DVS 機能の実証試験}

〈4・1〉 DG による DVS 機能の効果 DVS 機能の効果 について, IM を含む模擬系統で確認するために, 図 9 のよ うな実験回路を構成する。ここで, 各機器の定数 (表 3 参照) は, 2 章において検討した系統モデル相当の值とし, $10 \mathrm{kVA}$ をべースとして負荷が 1.5 (p.u.)，うち IM 負荷が $60 \%$, DG 出力が 0.4 (p.u.), 系統リアクタンスが約 0.32 (p.u.) である。

図 9 の実験回路に打いて，電圧低下率 100\%，継続時間 $70 \mathrm{~ms}$ の瞬低を発生させた場合の実験結果とシミュレーショ ン結果を図 10 に示す。DG の制御は 2 章と同様に Type1〜 Type3 の 3 通りとした。図 10(a-1) では, Type1 の DG が 運転停止に至る場合や Type2 の LVRT 機能のみの場合は, 負荷端の端子電圧は 0.4 (p.u.) 程度で低下したままであり, 回復しない。これに対し, Type3 の DG が LVRT 機能と DVS 機能を持つ場合は，1 秒以内に電圧が回復している。 図 10(b-1) では, Type1 や Type2 では瞬低回復後も回転数 は低下し続け，Type3ではIM の回転速度 78\%程度まで低 

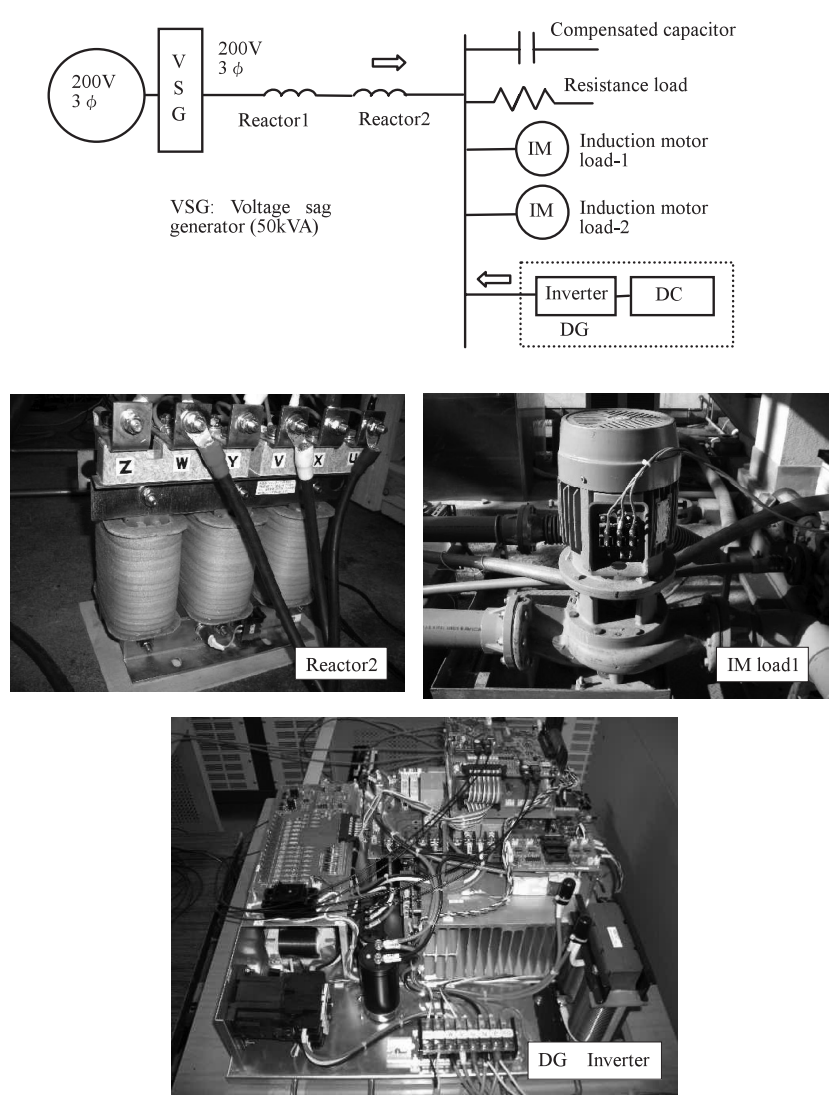

図 9 実験回路の概要図

Fig. 9. Schematic diagram of experimental set up.

\section{表 3 実験回路の諸定数}

Table 3. Parameters of experimental set up.

(a) Impedance (p.u., 10kVA, 200V base)

$\begin{array}{ll}\text { Reactor } 1 & 0.017+\mathrm{j} 0.118 \\ \text { Reactor2 } & 0.040+\mathrm{j} 0.205\end{array}$

(b) Load (p.u., 10kVA, 200V base)

$\begin{array}{lc}\text { Resistance load } & 0.60 \\ \text { IM load 1 } & 0.75+\mathrm{j} 0.35 \\ \text { IM load 2 } & 0.15+\mathrm{j} 0.08 \\ \text { DG } & -0.40 \\ \text { Capacitor } & -\mathrm{j} 0.61\end{array}$

(c) IM load parameter (p.u., machine base)

(IM load 1)

$\mathrm{X}_{1}=\mathrm{X}_{2}=0.091, \mathrm{X}_{\mathrm{m}}=4.58, \mathrm{R}_{1}=0.028, \mathrm{R}_{2}=0.054$,

$\mathrm{M}=0.47(\mathrm{~s}), \mathrm{T}_{\mathrm{m}} \propto \omega^{2}$, Loading $=1.0$ (rated kW base)

(IM load 2)

$\mathrm{X}_{1}=\mathrm{X}_{2}=0.093, \mathrm{X}_{\mathrm{m}}=1.95, \mathrm{R}_{1}=0.039, \mathrm{R}_{2}=0.060$,

$\mathrm{M}=0.61(\mathrm{~s}), \mathrm{T}_{\mathrm{m}} \propto \omega^{2}$, Loading $=1.0$ (rated $\mathrm{kW}$ base)

下後，定常状態に回復する。図 10(a-2), (b-2) ではシミュ レーション結果を示す。負荷端電圧, IM の回転数ともに実 験結果とほぼ一致している。

Type2, Type3 のケースにおける負荷の有効・無効電力の実 験結果とシミュレーション結果を図 11 に示す。図 11(a-1)

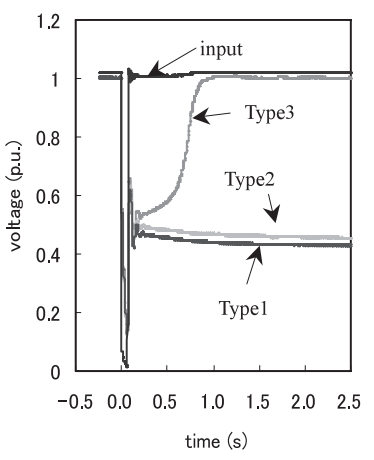

(a-1) Load's voltage

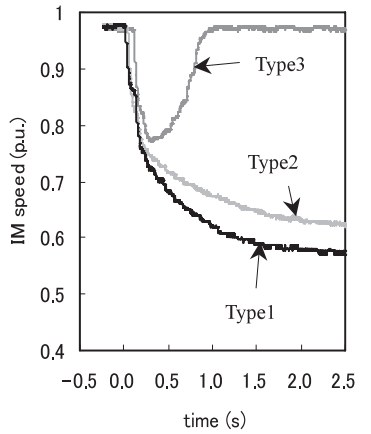

(b-1) IM speed (experiment)

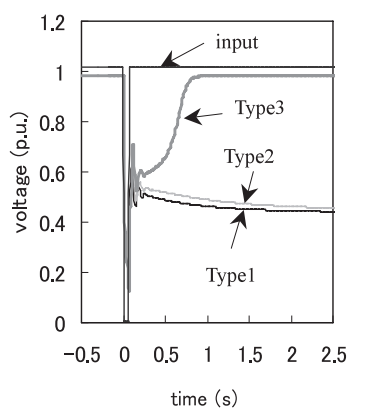

(a-2) Load's voltage

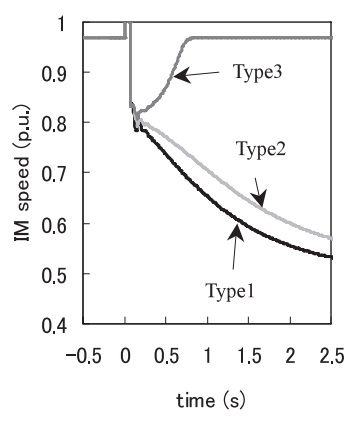

(b-2) IM speed (simulation)

図 10 異なる DG 制御による負荷の電圧安定性

$$
(\Delta \mathrm{t}=70 \mathrm{~ms}, \Delta \mathrm{V}=100 \%)
$$

Fig. 10. Load's voltage stability by different DG control.

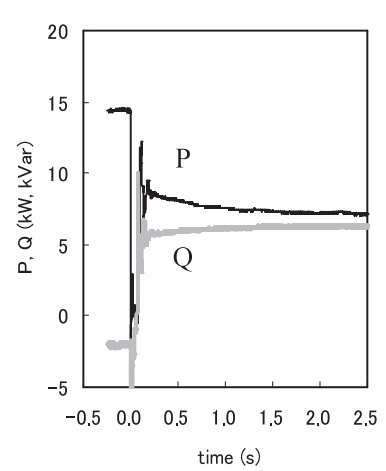

(a-1) Type2, experiment

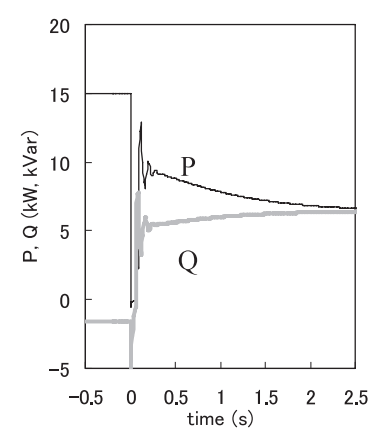

(a-2) Type2, simulation

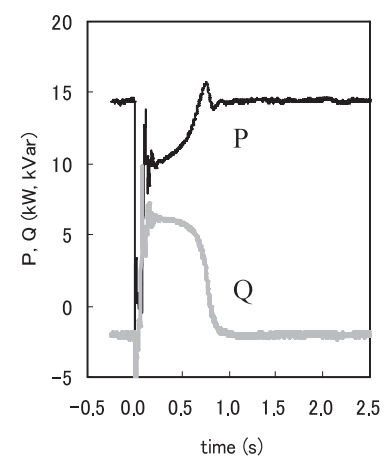

(b-1) Type3, experiment

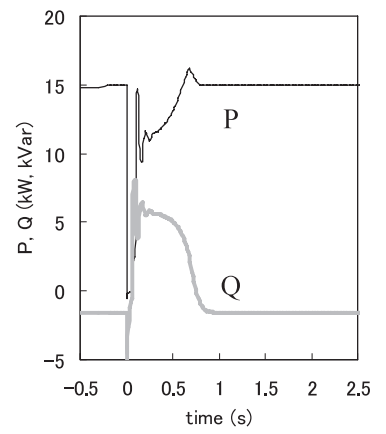

(b-2) Type3, simulation
図 11 瞬低による負荷の有効・無効電力

Fig. 11. Active and reactive power of load due to voltage sag. 


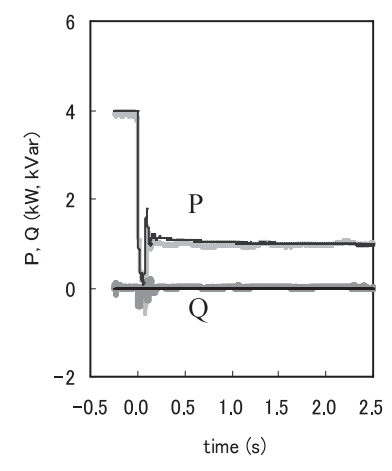

(a-1) Type2, experiment

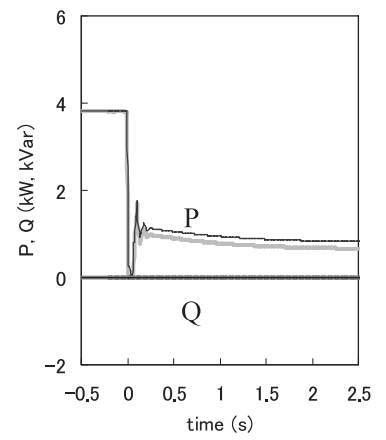

(a-2) Type2, simulation

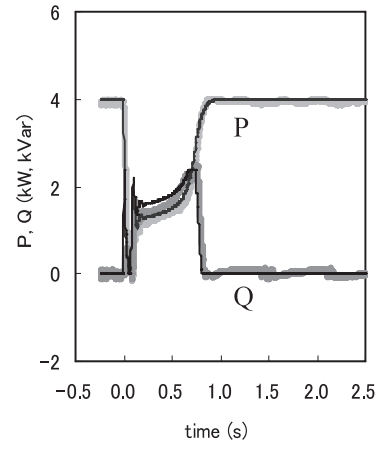

(b-1) Type3, experiment

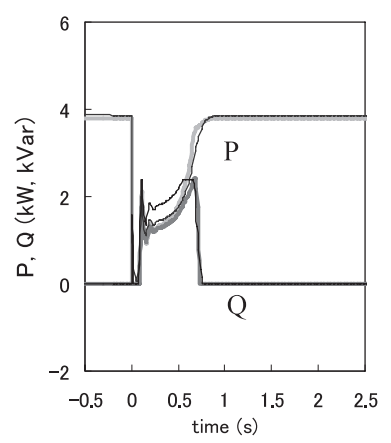

(b-2) Type3, simulation

図 12 瞬低による DG の有効・無効電力

Fig. 12. Active and reactive power of DG due to voltage sag.

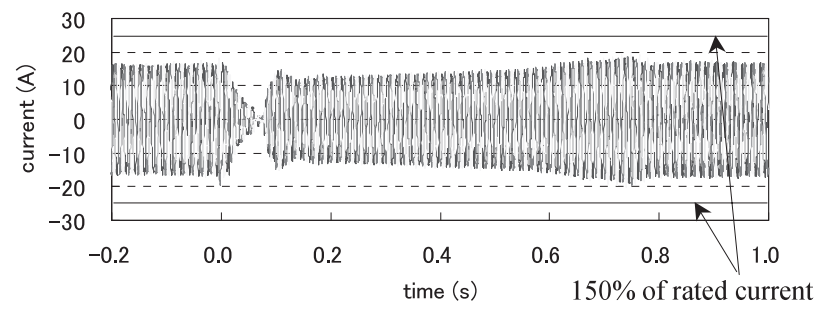

図 13 瞬低によるDG の電流（瞬時值, Type3）

Fig. 13. DG current due to voltage sag (instantaneous value, Type3).

は type2 の実験結果であるが，故障除去後，無効電力消費 は増加したままとなる。これに対し type3 の実験結果であ る図 11(b-1) では，無効電力消費は 1 秒以内に定常状態に 戻っている。Type2, Type3 のケースにおける DG 出力の 実験結果とシミュレーション結果を図 12 に示す。ここで 図中の黒線は，電圧值から換算した出力設定値を示してい る。図 12(a-1), (b-1) の実験結果では，ほほ設定值ど㧍り の DG 出力が得られている。図 11(a-2), (b-2), 図 12(a-2), (b-2) はシミュレーション結果を示す。瞬低による負荷の有 効・無効電力, $\mathrm{DG}$ の有効・無効電力ともに実験結果とほ ぼ一致している。

図 13 には Type3 の DG の電流（瞬時值）を示すが，有 効・無効電力制御による電流值はインバータの短時間許容 過電流の目安とした定格電流の $150 \%$ 以内である。

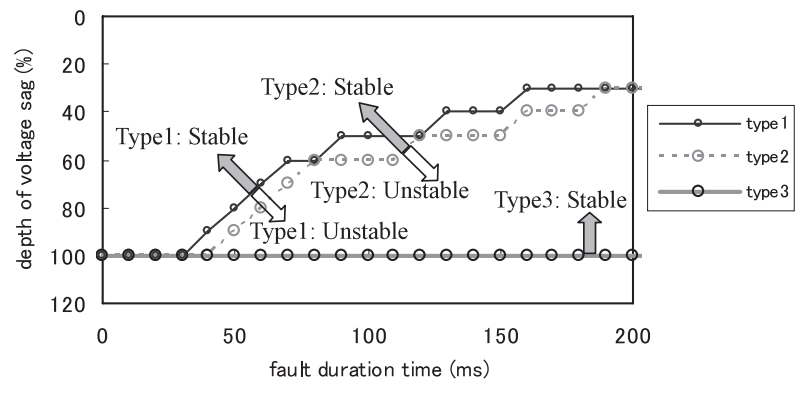

困 14 電圧低下率と故障継続時間による安定限界

Fig. 14. Stability limits due to depth of voltage sag and fault duration time.

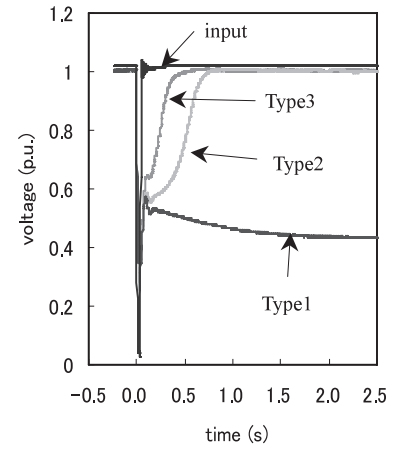

(a) Load's voltage

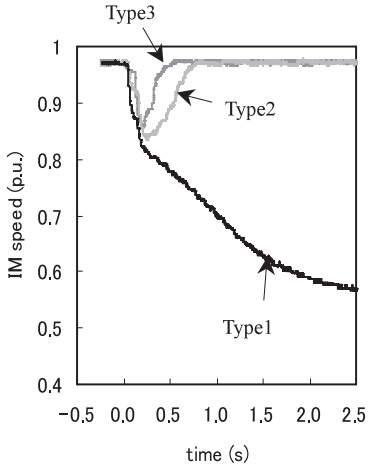

(b) IM speed
図 15 異なる DG 制御による負荷の電圧安定性 $(\Delta \mathrm{t}=40 \mathrm{~ms}, \Delta \mathrm{V}=100 \%)$

Fig. 15. Load's voltage stability by different DG control.

$\langle\mathbf{4} \cdot \mathbf{2}\rangle \quad$ 故障継続時間や電圧低下率による違い 図 14 に故障継続時間を $10 \mathrm{~ms}$ 毎, 電圧低下率を $10 \%$ 毎に変更し てIM がストールに至らない安定限界を調べた実験結果を 示す。この結果によれば, Type3, Type2, Type1 の順番で 安定限界の範囲が広く, LVRT 機能と DVS 機能の効果を確 認できる。特に, Type3においては故障継続時間 $300 \mathrm{ms,}$ 電圧低下率 100\%でも安定となった。

図 15 は，前節における故障継続時間を $70 \mathrm{~ms}$ から $40 \mathrm{~ms}$ に短縮した場合（電圧低下率は 100\%）の結果である。図 10 の結果と比較すると, 図 15 では, Type2 でも安定となっ ていることがわかる。また, Type3 は Type2 よりも速く電 圧が回復しており, DVS 機能の効果が確認できる。図 16 は，前節における電圧低下率を 100\%から 70\%に小さくし た場合（故障継続時間は $70 \mathrm{~ms}$ ) の結果である。図 10 の結 果と比較すると, 図 16 では, Type3 に加え Type2 も安定 となっている。Type2 は安定限界付近にあり, 故障除去後, IM の回転数は $80 \%$ 程度を 1 秒程度維持したままゆっくり と定常状態まで復帰している。この結果は, 図 2 の IM の トルク-速度曲線において Type2 の場合, IM の回転速度が 80\%程度で安定限界となる特性とほぼ一致している。

図 17 に, Type3 の場合について電圧低下率を 100\%, 故 


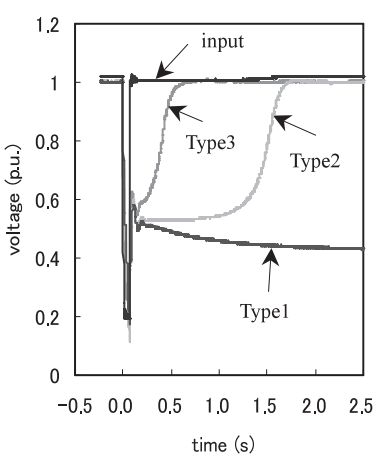

(a) Load's voltage

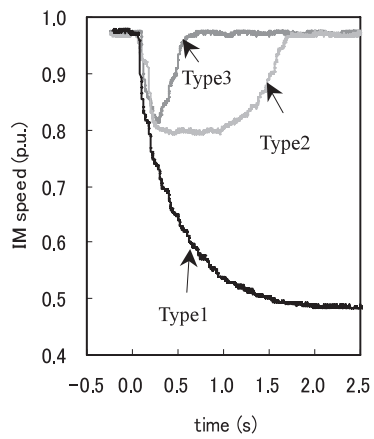

(b) IM speed
図 16 異なる DG 制御による負荷の電圧安定性

$(\Delta \mathrm{t}=70 \mathrm{~ms}, \Delta \mathrm{V}=70 \%)$

Fig. 16. Load's voltage stability by different DG control.

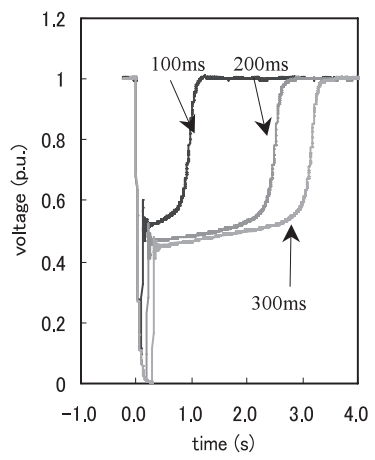

(a) Load's voltage

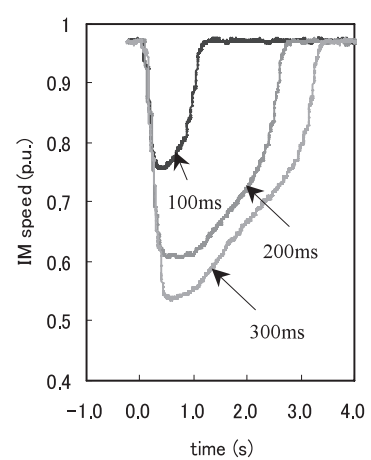

(b) IM speed
図 17 DVS 機能付きDG による負荷の電圧安定性

$(\Delta \mathrm{t}=100 \mathrm{~ms}, 200 \mathrm{~ms}, 300 \mathrm{~ms}, \Delta \mathrm{V}=100 \%)$

Fig. 17. Load's voltage stability by DG with DVS.

障継続時間を $100 \mathrm{~ms}$ から $300 \mathrm{~ms}$ まで長くした場合の結果 を示す。故障継続時間が長くなったため電圧が回復する時 間も長くなり，また IM の回転速度が $60 \%$ 以下になるもの の, 定常状態には復帰する。この結果は, 図 2 の IM のト ルクー速度曲線において, Type3 の場合, IM の回転速度が $60 \%$ 以下となっても安定となる特性とよく一致している。

\section{5. あとがき}

本論文において提案する有効・無効電力制御方法に基づ くDVS 機能付きインバータ連系装置を製作し, 瞬低試験 により下記のことを示した。

（1）市販のインバー夕連系装置のプログラム変更のみ により LVRT 機能と DVS 機能を実現できることを確認し た。特に, 提案する制御方法は, 短時間の過電流が定格電 流の $150 \%$ 以内に収まるため，現状のインバー夕容量を過 度に大きくすることなく実現できると考えられる。

（2）DG と IM を含む試験回路において，DVS 機能が ない場合は負荷の短時間電圧不安定現象が発生し, DVS 機 能により安定となることを実験で示した。これらは，IMの トルクー速度曲線から求められる特性やシミュレーション
結果とほぼ一致することを示した。

（3） DG の DVS 機能により，IM の電気的トルクが大 きくなるために, IM は回転速度が低下しても定常状態に復 帰できる。この機能により，瞬低に対して大幅に負荷の短 時間電圧安定性が改善され，瞬低継続時間が長く電圧低下 量が大きくても安定に定常状態に復帰できることを実験で 示した。

今後の課題としては，1実系統におけるDG は多台数で 構成されているため, 制御のばらつきや相互干渉の影響を 数台単位で実験的に評価すること, (2)瞬低中のエネルギー 抑制が困難な風力発電などで LVRT 機能と DVS 機能を実 現することが挙げられる。

本論文で示した実験結果は著者らの大規模系統でのシミュ レーション結果 ${ }^{(3) \sim(5)}$ を裏付けており, 今後導入される DG （特にインバータ連系 DG）は LVRT 機能と DVS 機能を備 える必要があると考える。インバー夕連系 DG は, 特別高 圧に連系されるものから低圧に連系されるものまで多岐に わたり，全てのインバータ DGについてそれらの機能が必 要か否かは, 今後の DG 導入量や電力系統側の増強状況に よる。しかし，少なくとも本論文で示したような不安定現 象が発生する可能性があることを認識した上で, 系統計画 · 運用を行っていくことが重要であると考える。

本研究の一部は，独立行政法人新エネルギー・産業技術 総合開発機構 (NEDO 技術開発機構) からの委託事業 (「系 統連系円滑化蓄電システム技術開発」新型蓄電池の実用化 技術開発）の一環として行われたものである。

(平成 19 年 8 月 24 日受付, 平成 19 年 12 月 17 日再受付)

\section{文献}

(1) A.E. Hammad and M.Z. El-Sadek: "Prevention of Transient Voltage Instabilities due to Induction Motor Loads by Static Var Compensators", IEEE Trans. Power Syst., Vol.4, No.3, pp.1182-1190 (1989-8)

(2) O.T. Tan, G.C. Paap, and M.S. Kolluru: "Thyristor-Controlled Voltage Regulators for Critical Induction Motor Loads During Voltage Disturbances", IEEE Trans. Energy Conv., Vol.8, No.1, pp.100-106 (1993-3)

(3) T. Ueda and S. Komami: "Dynamic Load Stability in Bulk Power System with High DG Penetration", IEEJ Trans. PE, Vol.127, No.2, pp.371-378 (2007-2) (in Japanese)

上田智之・駒見慎太郎：「分散型電源大量導入時に㧍ける動的負荷 の安定性解析」, 電学論 B, 127, 2, pp.371-378 (2007-2)

(4) T. Ueda and S. Komami: "Transient Stability Considering Dynamic Load in Bulk Power System with High DG Penetration", IEEJ Trans. PE, Vol.126, No.10, pp.969-976 (2006-10) (in Japanese) 上田智之・駒見慎太郎：「分散型電源大量導入時に抢ける動的負荷 を考慮した過渡安定度」, 電学論 B, 126, 10, pp.969-976 (2006-10)

(5) Y. Yamagishi and S. Komami: "Power System Dynamic Stability Analysis Considering Dynamic Load and Distributed Generation", IEEJ Trans. PE, Vol.126, No.10, pp.977-984 (2006-10) (in Japanese) 山岸良雄・駒見慎太郎：「動的負荷と分散型電源を考慮した電力系 統の動態安定度解析」, 電学論 B, 126, No.10, pp.977-984 (2006-10)

(6) N. Kanao, M. Yamashita, H. Yanagida, G.S. Kim, and S. Kikuhara: "Development of Voltage Dip generator Instrument with Power Regenerative Function", Proc. of the $13^{\text {th }}$ Annual Conference of Power \& Energy Society, IEE Japan, Vol.A, pp.659-660 (2002-8) (in Japanese)

金尾則一 ·山下益功・柳田孫肖・金光 植·菊原 聡:「電力回生機 能付き瞬低発生装置の開発」, 平成 14 年電気学会 $\mathrm{B}$ 部門大会, 分冊 A, pp.659-660 (2002-8) 
上田 智 之 (正員) 1968 年 8 月 5 日生。1992 年 3 月慶應義 塾大学理工学部電気工学科卒業。1994 年 3 月同 大学大学院理工学研究科電気工学専攻修士課程修 了。同年 4 月北陸電力 (株) 入社。現在, 同社技 術開発研究所勤務。
駒 見 慎太郎 （正員） 1952 年 9 月 13 日生。1 975 年 3 月東京

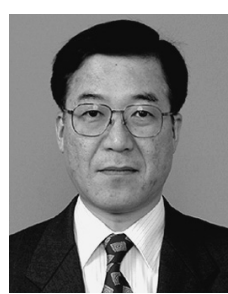

大学工学部電気工学科卒業。同年 4 月北陸電力

(株) 入社。現在，同社技術開発研究所部長。 